\title{
SIMBOLISME HAJI ORANG BUGIS: MENGUAK MAKNA IBADAH HAJI BAGI ORANG BUGIS DI BONE, SULAWESI SELATAN
}

\author{
Subair \\ IAIN Ambon \\ bairbone1976@gmail.com
}

\begin{abstract}
Hajj experiences fluidity when interpreted by Bugis, which has implications for meaningful symbolic aspects, tends to be mystical and contemplative. For the Bugis, the pilgrimage is a symbol of the transformation of one's selfhood, where hajj means reaching the highest position that a person can attain. Using haij attributes is a necessity. Attributes such as hajj clothing are highly valued because they have been blessed through the mappatoppo ritual. Aside from being a symbol of Hajj graduation, mappatoppo is also believed to be a condition of hajj perfection which is related to the ability to use the title of hajj and the appropriateness of wearing hajj clothing. The use of hajj clothing must be carried out at public events, if not, it is considered to be an insult to the status of the study. On the contrary, wearing hajj clothing by people who are not public pilgrimage is considered to be a person who has no shame (to de 'gaga siri'na), and undoubtedly will be sanctioned in the form of reproach and exclusion in social interaction.
\end{abstract}

Keywords: Bugis, Hajj, Symbolism of Hajj

\begin{abstract}
Abstrak
Ibadah Haji mengalami fluiditas ketika dimaknai orang Bugis yang berimplikasi pada aspek-aspek simbolik yang penuh makna, cenderung mistis dan kontemplatif. Bagi orang Bugis, haji adalah sebuah simbol transformasi kedirian seseorang, di mana dengan naik haji berarti telah mencapai posisi tertinggi yang mampu dicapai oleh seseorang. Memakai atribut haji merupakan keniscayaan. Atribut seperti busana haji sangat dihargai karena telah diberkahi melalui ritual mappatoppo. Selain sebagai simbol wisuda haji, mappatoppo juga diyakini sebagai syarat kesempurnaan haji yaitu yang berhubungan dengan kebolehan menggunakan gelar haji dan kepantasan memakai busana haji. Pemakaian busana haji harus dilakukan pada acara-acara publik, jika tidak maka dianggap melecehkan status kehajian. Sebaliknya, mengenakan pakaian haji oleh orang yang bukan haji di muka umum dianggap orang yang tidak punya rasa malu (to de'gaga siri'na), dan niscaya akan mendapat sangsi berupa celaan dan pengucilan dalam pergaulan sosial.
\end{abstract}

Kata Kunci: Orang Bugis, Ibadah Haji, Simbolisme Haji

\section{Pendahuluan}

Minat dan semangat warga Kabupaten Bone yang merupakan pusat suku Bugis di Sulawesi Selatan, untuk menunaikan ibadah haji tergolong sangat tinggi. Hasil analisis data pada Buku Data Haji Kabupaten Bone menunjukkan bahwa 0,62 persen penduduk Bone naik haji setiap tahunnya. ${ }^{1}$ Jumlah itu kurang lebih sebanding dengan angka pertambahan penduduk Bone setiap tahunnya, yaitu 0,6 persen. $^{2}$ Indikasi lain tingginya minat haji orang Bugis khususnya di

${ }^{1}$ Buku Data Jamaah Haji Bone Kantor Departemen Agama Kabupaten Bone.

${ }^{2}$ Biro Pusat Statistik Kabupaten Bone, Bone dalam Angka. (Watampone: Bappeda Kabupaten Bone, 2009). 
Bone adalah pada pemenuhan kuota haji. Setiap tahun kabupaten Bone selalu meminta dan memperoleh jatah kuota daerah lain yang tidak terpenuhi kuotanya. Hasil penelitian Nasrullah menunjukkan bahwa jumlah calon jemaah haji Bone yang menjadi daftar tunggu setiap tahunnya sangat tinggi sampai di atas rata-rata empat tahun. ${ }^{3}$

Tingginya angka jemaah haji umumnya digunakan sebagai indikasi dari dua hal penting. Pertama, meningkatnya ketakwaan dengan memenuhi rukun Islam kelima. Sebuah bukti bahwa kehidupan beragama semakin membaik. Kedua, hal itu menunjukkan pula membaiknya kemampuan ekonomi, Sebab untuk naik haji diperlukan biaya yang sangat tinggi, apalagi jika ukurannya adalah penghasilan petani yang pas-pasan untuk kebutuhan hidup sehari-hari.

Haji sebagai ibadah wajib dalam agama Islam yang syarat dan tata cara pelaksanaannya telah tertulis dalam teks-teks agama Islam telah mengalami fluiditas ketika dimaknai orang Bugis. Salah satu perwujudan fluiditas itu terlihat dari realitas haji dalam bentuk aspek-aspek simbolik yang penuh makna, cenderung mistis dan kontemplatif. Pada akhirnya, haji bagi orang Bugis bukan lagi sekedar pelaksanaan rukun Islam yang kelima. Haji juga tidak lagi tepat untuk mengukur tingkat religiositas dan ekonomi masyarakat. Sarjan menemukan bahwa banyak orang Bone menunaikan ibadah haji karena terobsesi pada aspek-aspek simbolik seperti busana dan gelar haji serta paham-paham keberkahan benda-benda Tanah Suci. ${ }^{4}$ Untuk mengungkap makna yang tersembunyi di balik simbol-simbol haji itu memang bukan perkara mudah, karena makna tersebut lebih bersandar pada keyakinan dari pada rasionalisme. Makna di sini merujuk kepada kognisi, afeksi, intensi, dan apa saja yang terpayungi dengan istilah "perspektif partisipan" atau subjek penelitian. ${ }^{5}$ Transparansi makna aspek simbolik haji itu hanya dapat diuraikan oleh subjek yang meyakini makna simbolis tersebut. Akan tetapi karena paham dan keyakinan itu bersifat faktual dan aktual, implikasinya dapat terlihat pada realitas sosial mereka.

\section{Teori dan Pendekatan yang Digunakan}

Menurut Geertz, agama adalah sistem kepercayaan yang di dalamnya meliputi aspek-aspek budaya, moral, hukum, dan sebagainya. Agama adalah sistem budaya, yang karenanya agama terdiri atas berbagai simbol sosio-kultural yang memberikan suatu konsepsi tentang realitas dan menafsirkan rencana untuknya. Pengertian itu mempunyai cakupan yang sangat luas, sehingga untuk keperluan keperluan penelitian ini, agama dibagi pada dua model untuk

${ }^{3}$ Nasrullah, Quota Haji dan Hubungannya dengan Konsep Istita'ah: Studi Kasus Daftar Tunggu Calon Jamaah Haji Kabupaten Bone (Skripsi, Sekolah Tinggi Agama Islam Negeri Watampone, 2002).

${ }^{4}$ Andi Sarjan, Studi tentang Paham dan Kepercayaan Suku Bugis (Bone) di Sekitar Pelaksanaan Ibadah Haji. Hasil Penelitian Kolektif STAIN Watampone (Watampone: STAIN Watampone, 1999).

${ }^{5}$ A. Chaedar Alwasilah, Pokoknya Kualitatif: Dasar-Dasar Merancang dan Melakukan Penelitian Kualitatif (Jakarta: Pustaka Jaya, 2002), h. 107-108. 
kerangka acuan, yaitu agama sebagai "model-model mengenai realitas" (models of reality) dan agama sebagai "model-model untuk realitas" (models for reality). ${ }^{6}$ Agama sebagai model-model mengenai realitas adalah agama dalam pemahaman dan pengamalan masyarakat dengan kata lain agama sebagai realitas sosial; karena itu bersifat konkret dan menggambarkan kongruensi struktural dengan objek yang digambarkan. Sementara itu agama sebagai modelmodel untuk realitas adalah berupa teori, dogma atau doktrin untuk suatu realitas; karena itu bersifat abstrak.

Haji merupakan salah satu model untuk realitas dalam agama Islam yang realitasnya sangat menonjol dalam pengalaman dan kehidupan beragama masyarakat di Indonesia. Karena sifatnya yang abstrak, haji dalam pemahaman dan realitas pelaksanaan oleh kaum Muslim, mengalami beberapa modifikasi setelah terlebih dahulu mengalami proses adaptasi dengan budaya masyarakat setempat. Haji sebagai model mengenai realitas, pada beberapa daerah tampak berbeda dengan haji sebagai model untuk realitas.

Dalam makalah ini terdapat dua konsep utama; aspek simbolik haji dan orang Bugis. Aspek simbolik haji adalah istilah yang digunakan untuk merujuk seluruh simbol-simbol kehajian, terutama pakaian dan perilaku khas haji. Menurut Thorsten Veblen, semua pakaian dalam seluruh modelnya adalah simbolik, semakin khas pakaian kita semakin terbatas kita bertindak. Pakaian adalah salah satu cara melambangkan status sosial seseorang dalam masyarakat.7 Sedangkan konsep orang Bugis adalah istilah untuk komunitas suku Bugis yang merupakan suku terbesar yang mendiami wilayah Sulawesi Selatan. Dalam konteks ini, orang Bugis yang dimaksud adalah orang Bugis di kabupaten Bone.

Untuk memahami dua konsep itu, digunakan pendekatan interaksionisme simbolik. Pendekatan interaksi simbolik tidak hanya menganalisis kehadiran manusia di antara sesamanya, tetapi juga motif, sikap, nilai yang mereka anut dalam privasi mereka. ${ }^{8}$ Dasar pemikiran dari interaksionisme simbolik adalah bahwa manusia adalah makhluk pencipta, pengguna dan pencinta simbol. Bahasa, pakaian, jabatan, status dan lain-lain adalah simbol. Dalam sebuah simbol, ada makna tertentu yang menurut pemakainya berharga. Dan orang yang memakai simbol tertentu ketika ia berinteraksi dengan orang lain berharap agar orang lain itu memberikan penilaian atau citra sesuai dengan pemahamannya, atau kalau sebaliknya, niscaya ia akan kecewa. ${ }^{9}$

Pendekatan interaksi simbolik bertumpu pada tiga premis; pertama, manusia bertindak terhadap sesuatu berdasarkan makna-makna yang ada pada

${ }^{6}$ Clifford Geertz, The Interpretation of Cultures: Selected Essais (New York: Basic Books Inc. Publication, 1973), h. 93.

7Lihat Deddy Mulyana \& Jalaluddin Rakhmat, ed., Komunikasi antar Budaya (Cet. VI, Bandung: Remaja Rosda Karya), h. 97.

8Deddy Mulyana, Metodologi Penelitian Kualitatif: Paradigma Baru Ilmu Komunikasi dan Ilmu Sosial Lainnya (Cet. I, Bandung: Remaja Rosdakarya, 2001), h. 60.

9 Ian Craib, Teori-Teori Sosial Modern; Dari Parsons sampai Habermas. Diterjemahkan oleh Paul S. Baut dan T. Affendi. (Jakarta: RajaGrafindo Persada, 1994), h. 112. 
sesuatu itu bagi mereka; kedua, makna tersebut berasal dari interaksi sosial seseorang dengan orang lain; dan ketiga, makna-makna tersebut disempurnakan di saat proses interaksi sosial berlangsung. ${ }^{10}$

\section{Simbolisme Haji dalam Kebudayaan Orang Bugis}

\section{Pakaian dan Atribut Haji}

Pakaian dan atribut kehajian adalah identitas haji yang paling menonjol. Keduanya merupakan berkah dari haji yang pertama sekali dan paling dihargai oleh orang Bugis. Karenanya, haji yang tidak memakai busana haji pada waktu pulangnya, maka oleh orang lain hajinya dianggap tidak berberkah.

Pada dasarnya pakaian haji ada dua yaitu pakaian yang dipakai sewaktu melaksanakan ibadah haji di Tanah Suci yang disebut pakaian ihram dan pakaian haji setelah menjadi haji. Pakaian ihram dipakai oleh seluruh jemaah haji dari seluruh dunia sedangkan pakaian yang dipakai setelah seseorang menjadi haji adalah khas dan hanya dipakai oleh orang Bugis yang sudah haji. Busana yang khas inilah yang dimaksud dengan pakaian atau busana haji dalam tulisan ini.

Busana haji bagi orang Bugis terdiri atas busana yang dipakai pada acara-acara resmi dan busana yang dipakai sehari-hari. Busana untuk pemakaian resmi itu pun terbagi atas busana lengkap dan busana yang sederhana. Busana yang resmi adalah kabe' atau tippolo (sorban) bagi haji laki-laki. Sedangkan busana resmi yang sederhana dipakai pada acaraacara adat seperti perkawinan dan acara-acara adat lainnya, terdiri dari taliling saja atau terispa' saja bagi haji perempuan dan songkok haji (peci putih) saja bagi haji laki-laki. Itulah busana yang akan membedakan antara seorang haji dengan bukan haji. Busana yang dipakai sehari-hari tidak jauh berbeda dengan busana sederhana ini hanya saja taliling atau terispa' diganti dengan cipo'-cipo' haji yaitu sejenis topi khas perempuan yang dirancang khusus menyerupai taliling, tapi bukan taliling. Haji laki-laki lebih simpel karena biasanya mereka hanya cukup dengan memakai peci putih.

Di bawah ini adalah bagian-bagian dari busana haji orang Bugis.

a. Kabe'

Kabe adalah baju panjang yang menutupi seluruh tubuh pemakainya, biasanya berwarna hitam atau merah. Melihat dari bentuknya, tampaknya diadaptasi dari pakaian orang di gurun Arabia. Oleh jemaah haji, pakaian itu dibeli di Bone sendiri, tetapi ada juga sebagian yang membelinya di Mekah. Menurut cerita responden yang diwawancarai, harga kabe' di Bone cenderung lebih murah dibanding

10Imam Suryoprayogo dan Tobroni, Metodologi Penelitian Sosial Agama (Cet. I, Bandung: Remaja Rosdakarya, 2001), 105. 
dengan harganya di Mekah. Sedangkan mutunya kurang lebih sama karena konon katanya kabe' yang dijual di Mekah berasal dari Bone juga. Kabe' itu di bawa oleh anggota jemaah juga yang kemudian dijual melalui orang Bugis yang ada di sana.

Kabe' oleh sebagian orang Bugis dianggap sebagai pakaian yang penuh berkah. Tidak jarang kita mendengar orang berkata, "Mabarakka mutoha rita taue narekko mappake kabe'i" (sungguh kelihatan "barakah" sekali orang yang memakai kabe').

b. Taliling

Taliling adalah sejenis kerudung yang cara pemakaiannya dililitkan di kepala. Cara pemakaian taliling tergolong susah, dibutuhkan sebuah keterampilan khusus untuk melakukannya. Karena pemakaiannya yang rumit, biasanya taliling hanya dipakai oleh haji perempuan pada saat haid sehingga dipakai dalam waktu lama. Berbeda dengan kabe' yang jarang dipakai kecuali hanya pada keadaan tertentu saja, taliling selalu dipakai pada setiap kegiatan yang bersifat resmi. Cara pemakaiannya ditutupi dengan sebuah kerudung (terispa'). Jemaah biasanya menyiapkan taliling dari tanah air atau membelinya di Arab Saudi.

c. Terispa'

Terispa' adalah kerudung yang terbuat kain transparan, biasanya dari bahan sutera. Di sepanjang pinggirannya dihiasi dengan manikmanik serta ditengahnya dihiasi gambar atau motif bunga dengan sulaman benang emas. Warna yang dominan pada terispa' adalah merah. Pada ritual mappatoppo, terispa' inilah yang dipasangkan oleh syekh.

Terispa' adalah ciri kehajian perempuan yang paling lazim. Terispa' umumnya digunakan untuk menutupi taliling, akan tetapi kalau mau ringkas biasa juga digunakan untuk menutupi jenis penutup kepala yang oleh orang Bugis disebut cipo-cipo. Terispa' adalah pembeda antara haji dengan bukan haji, apabila keduanya sama-sama memakai cipo'-cipo'.

d. Songkok Haji, Surubeng dan Tippolo.

Ketiga jenis busana itu adalah identitas kehajian pada haji lakilaki. Songkok haji adalah peci berbentuk bundar yang terbuat dari kain berwarna putih, atau biasa juga dihiasi dengan sulaman benang emas. Surubeng adalah sorban yang dipakai untuk menutupi kepala. Sebenarnya sorban tidak hanya dipakai oleh haji saja karena semua orang yang dianggap sebagai ustaz juga sering memakainya. Ia lebih merupakan pakaian taqwa yang dipakai ketika melakukan shalat atau memberi ceramah. Perbedaannya adalah kalau dipakai oleh orang 
yang bukan haji, ia cukup disangkutkan dipundak saja sedangkan

\section{Gelar}

pada haji dipakai sebagai penutup kepala.

Gelar haji adalah identitas kehajian selain pakaian. Gelar haji pada seorang haji akan melekat terus di namanya, melebihi identitas atau gelargelar lain. Panggilan orang lain kepadanya berubah menjadi panggilan haji. Seorang bangsawan dengan gelar Petta akan dipanggil dengan Petta Hajji, seorang dengan gelar Puang kemudian menjadi Puang Hajji. Bahkan tidak sedikit kasus, anak-anak dan keluarganya pun mengubah panggilan mereka menjadi haji. Jadi panggilan "ajikku" oleh seorang anak berarti ditujukan kepada orang tuanya. Aji urane (haji laki-laki) adalah panggilan untuk ayah dan aji makkunrai (haji perempuan) untuk ibu.

Bagi orang awam, terutama yang tinggal di daerah pedesaan, gelar haji ditujukan untuk menunjukkan identitasnya sebagai haji. Dengan identitas itu, penghargaan-penghargaan sosial yang disediakan oleh sistem sosialnya bagi status haji akan ia peroleh dari masyarakat. Kesalahan penyebutan gelar haji itu, misalnya pada kartu undangan, berakibat ia akan jengkel dan tidak akan menanggapinya. Para haji itu, bahkan kadang tidak mau menyahut atau pura-pura cuek kalau dalam pergaulan seharihari tidak dipanggil dengan gelar hajinya. Sedangkan bagi kalangan terdidik atau bagi yang tinggi pemahaman agamanya, gelar haji menjadi semacam motivasi untuk menjaga sikap dan perbuatan. Meskipun selalu memakainya, golongan ini akan memakluminya apabila suatu waktu ia dipanggil atau disapa tanpa gelar haji.

Bagaimanapun, bagi sebagian besar orang Bugis gelar haji adalah sebuah gelar yang prestisius, yang dengan mendapatkannya seseorang akan naik derajat sosialnya. Meskipun pengaruhnya tidak sebesar aspek busana haji dalam memotivasi mereka naik haji, tapi dari penuturan mereka dan hasil pengamatan tampak bahwa gelar haji adalah salah satu aspek yang memotivasi. Mereka tampak begitu senang ketika dipanggil hajji dan sebaliknya akan kelihatan kecewa kalau tidak dipanggil hajji.

\section{Pemaknaan atas Simbol-Simbol Haji dan Implikasinya}

Ada dua konsep yang melandasi pemahaman orang Bugis terhadap haji, yaitu konsep kesuksesan hidup dan konsep takdir. Haji dianggap sebagai prestasi tertinggi seorang manusia karena merupakan simbol kesuksesan dalam kehidupan dunia sekaligus sebagai kesuksesan sebagai seorang Muslim. Takdir, karena menurut mereka meskipun seseorang mempunyai harta yang melimpah tetap saja tidak bisa dipergunakannya untuk memenuhi biayanya menunaikan haji. 


\section{Implikasi pada Status Sosial}

Status sosial adalah hal yang mewujudkan unsur dalam teori sosiologi sistem lapisan masyarakat, di samping peranan. Status sosial merupakan unsur baku dalam sistem stratifikasi, dan mempunyai arti penting bagi sistem sosial. Status sosial adalah tempat seseorang secara umum dalam masyarakatnya sehubungan dengan orang-orang lain, dalam arti lingkungan pergaulannya, prestisenya, dan hak-hak serta kewajibankewajibannya. ${ }^{11}$ Sedangkan yang diartikan sebagai sistem sosial adalah pola-pola yang mengatur hubungan timbal-balik antar individu tersebut. ${ }^{12}$

Selain merupakan ibadah wajib dan rukun Islam, haji juga telah menjadi sebuah sistem simbol yang kompleks. Seorang yang sudah melaksanakan ibadah haji secara otomatis akan mendapatkan sebuah penghargaan sosial dari masyarakat atas kehajiannya sehingga karenanya ia harus menyesuaikan perilakunya dengan status sosial baru itu. Dengan statusnya sebagai haji, seorang haji menjadi golongan atas dalam masyarakat.

Beberapa indikasi naiknya tingkat status seseorang karena kehajiannya, misalnya dapat dilihat pada acara perkawinan adat Bugis:

a. Tugas mengantar dan menjemput pengantin dilakukan oleh kalangan keluarga dekat pengantin atau orang lain yang diundang khusus karena status sosialnya. Selain karena jabatannya, orang yang diundang adalah para haji di kampung itu. Bagi pemilik acara, ada kebanggaan tersendiri jikalau acaranya dihadiri oleh banyak haji. Demikian pula pada acara mappaenre' doi (pesta pembayaran uang belanja dan penetapan hari perkawinan).

b. Setelah dihapuskannya sistem perbudakan, pekerjaan dapur seperti memasak, mengambil air dan mencuci piring, saat ini dikerjakan oleh perempuan yang memiliki kedekatan hubungan dengan pengantin, biasanya keluarga atau tetangga. Seorang perempuan setelah berstatus haji tidak lagi bekerja di sektor belakang seperti itu, melainkan bertugas di sektor depan seperti menjemput tamu atau mengatur tamu.

Pada acara pesta perkawinan, atau acara-acara adat lainnya terdapat pola pengaturan umum untuk tata letak orang-orang yang terlibat dalam acara itu. Pengaturan itu dilakukan berdasarkan status sosial seseorang. Pola itu dapat digambarkan sebagai berikut:

a. Pada acara pesta pernikahan, barisan penjemput tamu, mulai dari luar: kelompok penjemput dengan pakaian adat Bugis, barisan penjemput yang mengapit jalan, barisan sebelah kiri adalah keluarga yang turut 256), h. 265

11Soekanto, Soerjono, Sosiologi: Suatu Pengantar (Cet. XXXII, Jakarta: RajaGrafindo Perkasa, 12Ralph Linton, The Studi of Man: An Introduction (New York: Appleton Century Crofts, 1956), h. 105. 
mengundang dan haji laki-laki, sedangkan barisan sebelah kanan adalah kelompok haji perempuan berbusana haji. Bagi orang Bugis, bagian kanan adalah simbol keutamaan.

b. Pada acara di dalam ruangan, kelompok haji duduk di sebelah kanan pintu serta agak jauh dari pintu. Sedangkan non haji duduk di sebelah kiri pintu masuk, biasanya terstruktur dari pintu. Semakin terhormat seseorang, maka semakin jauh ia dipersilahkan duduk dari pintu masuk.

c. Pekerjaan perempuan sebelum haji adalah memasak, menyajikan makanan, mencuci piring, dan semua urusan dapur lainnya. Sedangkan setelah haji, pekerjaannya adalah menemani tamu di luar atau sebagai tamu, dan mengantar atau menjemput pengantin.

d. Pada kegiatan kegamaan yang dilakukan di mesjid, kelompok haji duduk di saf (barisan) paling depan, membentuk barisan tersendiri. Biasanya, saf depan memang sengaja dikosongkan untuk memberi kesempatan para haji mendudukinya. Hal itu menjadi mudah mengingat jumlah dan siapa-siapa saja yang haji di sebuah kampung diketahui dengan pasti oleh masyarakat.

Abdul Salam dalam desertasinya menulis bahwa orang Bugis di Bone berlomba-lomba menunaikan ibadah haji tanpa didasarkan pada kemampuan dan syarat-syarat yang diperlukan. ${ }^{13}$ Umumnya mereka naik haji demi untuk memperoleh status sosial dalam masyarakat karena bagi mereka predikat haji merupakan kebanggaan sosial. Menurut Salam, fenomena itu terjadi karena tingginya sikap kompetitif yang dimiliki oleh orang Bugis dan merupakan salah satu refleksi dari budaya siri'.

Tingginya jumlah jemaah haji dapat dipakai untuk mengukur tingkat ketakwaan dan perekonomian sebuah masyarakat. Tetapi di kabupaten Bone tampaknya indikasi ini kurang tepat. Jumlah jemaah haji yang cukup tinggi lebih disebabkan oleh karena para responden sangat terobsesi pada aspek-aspek simbolik haji. Bagi kebanyakan mereka, haji merupakan sekedar sebagai simbol saja karena kenyataannya, pelaksanaan ibadah hajinya banyak yang tidak sesuai dengan tuntunan haji menurut syariat Islam dan setelah menjadi haji tidak ada perubahan sikap dalam hal peningkatan kualitas ketaqwaan.

Kalaupun ada yang berubah, itu adalah harga diri yang menjadi lebih tinggi dari sebelumnya sebagai akibat naiknya status sosialnya. Fenomena itu tidak hanya terjadi di pedesaan saja seperti sangkaan banyak orang, akan tetapi juga dapat dengan mudah ditemukan di daerah yang sedang berkembang menuju budaya perkotaan. Selain itu, dari pengamatan

${ }^{13}$ Abdul Salam, Implementasi dan Sosialisasi Siri': Studi Kasus pada Enam Keluarga Bugis Bone di Sulawesi Sekatan (Desertasi pada Program Pascasarjana Universitas Padjdjaran, Bandung, 2000), h. 192. 
penulis, umumnya para responden itu hidupnya pas-pasan dalam arti penghasilan pertahun mereka biasa-biasa saja kalau tidak menyebutnya rendah. Rumah mereka juga jauh dari kesan mewah, juga pola hidupnya.

\section{Implikasi pada Komposisi Haji Perempuan dan Laki-laki}

Implikasi lain dari aspek-aspek simbolik haji adalah adanya perbedaan signifikan antara jumlah jemaah haji perempuan dengan haji laki-laki. Perbedaan yang signifikan itu merupakan implikasi dari status sosial dan pakaian haji sekaligus. Kedua hal itu merupakan faktor yang memotivasi kebanyakan informan dalam menunaikan ibadah haji.

Berdasarkan data dari Buku Haji Kabupaten Bone Kantor Departemen Agama Kabupaten Bone, perbandingan yang signifikan antara jumlah jemaah haji perempuan dengan jemaah haji laki-laki, yaitu rata-rata 72:28 setiap tahunnya. Di lapangan, jemaah haji asal Bone sangat kontras dengan jemaah haji daerah lainnya karena komposisinya yang mayoritas perempuan. Selain mayoritas perempuan, rata-rata masih berusia muda. Data statistik dari sumber yang sama menunjukkan bahwa jemaah haji yang berusia 39 tahun ke bawah sebanyak 49, 4 persen, seimbang dengan jumlah jemaah haji yang berusia di atas 40 tahun ke atas.

Data dari Buku Haji Kabupaten Bone Kantor Departemen Agama Kabupaten Bone menunjukkan bahwa kebanyakan perempuan yang menunaikan ibadah haji tersebut adalah Ibu Rumah Tangga. Ini berarti bahwa banyak jemaah haji perempuan yang sudah berkeluarga berangkat dengan tidak ditemani oleh muhrimnya (suaminya) sekaligus membantah alasan komposisi jumlah penduduk perempuan dan laki-laki sebagai penyebab dari adanya selisih antara jumlah haji perempuan dan haji lakilaki. Hal itu juga menggambarkan betapa perempuan Bugis memiliki semangat untuk menunaikan ibadah haji yang lebih tinggi dari laki-laki.

Menurut penulis, ada beberapa alasan mengapa jumlah jemaah haji perempuan lebih banyak dari laki-laki, di antaranya adalah sebagai berikut:

Pertama, faktor status sosial; status seseorang meningkat dalam stratifikasi sosial setelah ia melaksanakan ibadah haji. Perempuan menunaikan ibadah haji sangat dimotivasi oleh kegiatan-kegiatan adat. Status sosial itu utamanya terlihat pada acara-acara adat seperti perkawinan pada seluruh tahapan tradisinya. Perempuan yang diundang dan terlibat pada acara itu hanya yang berstatus haji, sedangkan pada kelompok laki-laki, kehajian seseorang memberinya kesempatan untuk menempati posisi-posisi duduk yang utama, yang disediakan khusus bagi warga masyarakat kelas satu atau kelas dua.

Kedua, faktor pekerjaan. Biasanya seorang suami mendahulukan istrinya karena setelah si istri berangkat, ia masih bisa bekerja untuk mengumpulkan biaya untuk dirinya sendiri. 
Ketiga, faktor adat; ada kepercayaan (sennung-sennungeng) pada sebagian besar responden bahwa mendahulukan istri menunaikan ibadah haji akan membuat jalan suaminya lebih mudah untuk berangkat berikutnya. Sebaliknya, dengan mendahulukan suami, maka peluang istri dipercaya akan sulit. Selain itu, menaikkan istri ke Tanah Suci merupakan penghargaan tertinggi suami pada istrinya. Secara moral, seorang suami mendahulukan dirinya sendiri sebelum istrinya akan dicela oleh masyarakat. Penulis tidak menemukan satu kasus pun seorang suami naik haji lebih dahulu dari istrinya, kecuali atas penuturan informan dan responden saja.

Keempat, faktor fanatisme agama, fanatisme agama lebih menonjol pada perempuan dari pada laki-laki. Selain itu, diharapkan seorang Ibu Rumah Tangga setelah menunaikan ibadah haji ia akan menjadi ibu yang lebih baik dalam mendidik anak-anaknya.

\section{Implikasi pada persepsi Orang Bugis terhadap Ibadah Haji}

Pada hampir semua masyarakat Sulawesi Selatan, haji lebih dipahami sebagai sebuah prestise dan status sosial dari pada haji sebagai ibadah sebagaimana yang diperintahkan oleh syariat Islam. Mereka lebih dimotivasi oleh oleh faktor-faktor sosial dan paham-paham keberkahan daripada faktor ibadah atau menunaikan kewajiban.

Hal itu dapat dilihat pada beberapa fenomena, di antaranya sebagai berikut: Pertama, ada indikasi masyarakat lebih terorientasi oleh faktor prestise haji yang ukurannya adalah busana haji. Busana haji adalah simbol kehajian yang paling menonjol. Pakaian merupakan motivator haji terkuat orang Bugis naik haji, khususnya yang masih awam. Argumen untuk menjelaskan preposisi ini adalah tingginya angka perbedaan antara jumlah jemaah haji perempuan dari pada jumlah haji laki-laki, karena dimensi simbolistis pakaian haji perempuan lebih besar dari pada pakaian haji lakilaki. Karena alasan ini pulalah, para suami mengalah mendahulukan isterinya naik haji dari pada dirinya sendiri.

Kedua, ada indikasi kuat masyarakat di lokasi penelitian naik haji untuk memperoleh status sosial. Status sosial itu biasanya diukur dari penghargaan masyarakat terhadap seseorang. Pada acara-acara pernikahan, yang diundang untuk terlibat adalah mereka yang sudah berstatus haji. Perempuan yang berstatus haji pada acara perkawinan tidak lagi bertugas di bagian belakang yaitu urusan dapur akan tetapi bersamasama dengan para laki-laki duduk di depan sebagai kelompok orang-orang terhormat. Sebelum berstatus haji, biasanya perempuan memang harus bertugas di bagian dapur seperti memasak, mengatur makanan, dan mencuci piring sedangkan setelah haji, maka tidak diperbolehkan lagi. Banyak responden perempuan mengaku sebelum berstatus haji tidak pernah ke acara pernikahan akan tetapi setelah haji menjadi sangat rajin. 
Ketiga, berdasarkan informasi informan mantan petugas haji, jemaah haji Bugis kebanyakan hanya mementingkan fardu-fardu haji saja dalam pelaksanaan ibadah hajinya dan cenderung mengabaikan sunnah-sunnah haji seperti shalat berjamaah. Umumnya mereka memilih jenis haji tamattu, yaitu jenis pelaksanaan ibadah haji yang tergolong mudah dan pelanggaran-pelanggaran yang dilakukan dapat ditutupi dengan membayar dam atau denda. Akibatnya, banyak dari mereka yang seenaknya tidak menghiraukan ibadah-ibadah yang seharusnya dilakukannya dan lebih memilih untuk pergi berbelanja. Prinsip mereka ketika ditanya tentang itu adalah, "Puang Alla Taala'mi missengngi" (Hanya Allah Taala yang tahu).

Pemahaman orang Bugis terhadap haji seperti itu sudah menjadi pola pikir. Pola pikir itu tumbuh secara bertahap namun menghujam dalam ke jiwa orang Bugis. Mengakar karena pola pikir itu dibentuk oleh kultur, bukan rasio. Pada masyarakat yang sedang berkembang, pola pikir dibentuk oleh kultur dan akhirnya menjadi kultur, bukan oleh pikiran. Orang mengikuti sesuatu yang diyakininya telah dilakukan oleh leluhurnya secara turun temurun, tanpa mempertanyakan kebenaran atau keabsahan ikutan itu.

\section{Simpulan}

Bagi orang Bugis, haji adalah sebuah simbol transformasi kedirian seseorang, di mana dengan naik haji berarti telah mencapai posisi tertinggi yang mampu dicapai oleh seseorang. Setidaknya terdapat dua konsep yang melandasi pemahaman terhadap haji, yaitu pertama, konsep kesuksesan hidup; haji adalah prestasi tertinggi seorang individu karena simbol kesuksesan hidup seseorang dalam kehidupan dunianya sekaligus sebagai simbol kesempurnaan agama seorang Muslim. Kedua, konsep takdir; haji adalah takdir sehingga meskipun seseorang mempunyai harta yang melimpah kalau belum takdirnya tetap saja tidak bisa naik haji. Sebaliknya, meskipun miskin kalau sudah dipanggil oleh Allah swt. maka ia akan naik haji, bagaimanapun caranya.

Memakai atribut haji merupakan keniscayaan bagi seseorang haji. Atribut seperti busana haji sangat dihargai karena telah diberkahi melalui ritual mappatoppo. Selain sebagai simbol wisuda haji, mappatoppo juga diyakini sebagai syarat kesempurnaan haji yaitu yang berhubungan dengan kebolehan menggunakan gelar haji dan kepantasan memakai busana haji. Pemakaian busana haji harus dilakukan pada acara-acara publik, jika tidak maka dianggap melecehkan status kehajian, terutama bagi haji perempuan. Sebaliknya, mengenakan pakaian haji oleh orang yang bukan haji di muka umum dianggap orang yang tidak punya rasa malu (to de'gaga siri'na), dan niscaya akan mendapat sangsi berupa celaan dan pengucilan dalam pergaulan sosial. 


\section{Referensi}

Ali, Andi Muhammad, 1986. Bone Selayang Pandang. Watampone: t.p.

------, 1989. Mutiara yang Terpendam. Watampone: Pemerintah Daerah Tingkat II Bone.

Alwasilah, A. Chaedar, 2002. Pokoknya Kualitatif: Dasar-Dasar Merancang dan Melakukan Penelitian Kualitatif. Jakarta: Pustaka Jaya.

Ba-Yunus, Ilyas dan Farid Ahmad, 1996. Sosiologi Islam dan Masyarakat Kontemporer. Diterjemahkan oleh Hamid Basyaib, Bandung: Mizan.

Berger, Peter L., 1967. Sacred Canopy. New York: Doubleday.

-----, 1991. Langit Suci: Agama sebagai Realitas Sosial. Jakarta: LP3ES.

Berger, Peter, L. and Thomas Luckman, 1990. Tafsir Sosial atas Kenyataan: Risalah tentang Sosiologi Pengetahuan. Jakarta: LP3ES.

Biro Pusat Statistik Kabupaten Bone, 2009. Bone dalam Angka. Watampone: Bappeda Kabupaten Bone.

Boullata, Issa J., 2001. Dekontruksi Tradisi: Gelegar Pemikiran Arab Islam. Diterjemahkan oleh Imam Khoiri. Yogyakarta: LkiS.

Al-Bukhari, 1981. Shahih al-Bukhari, Juz II, Beirut: Dar al-Fikr.

Craib, Ian, 1994. Teori-Teori Sosial Modern; Dari Parsons sampai Habermas. Diterjemahkan oleh Paul S. Baut dan T. Affendi. Jakarta: RajaGrafindo Persada.

Geertz, Clifford, 1973. The Interpretation of Cultures: Selected Essais. New York: Basic Books Inc. Publication.

Hamid, Abu, 1991. Nilai-Nilai Budaya dan Perubahan Sosial: Suatu Pengenalan Budaya Sulawesi Selatan. Ujung Pandang: Universitas Hasanuddin.

Hendropuspito, 1983. Sosiologi Agama. Yogyakarta: Kanisius.

Kahmad, Dadang. 2002. Sosiologi Agama. Cet. kedua, Bandung: Remaja Rosdakarya.

Kantor Departemen Agama Kabupaten Bone, Buku Data Haji Kabupaten Bone.

Linton, Ralph, 1956. The Studi of Man: An Introduction. New York: Appleton Century, Crofts.

Mattulada, 1983. "Agama Islam di Sulawesi Selatan" dalam Taufik Abdullah (ed.), Perubahan Sosial. Jakarta: Rajawali Press.

Mulyana, Deddy. 2001. Metodologi Penelitian Kualitatif: Paradigma Baru Ilmu Komunikasi dan Ilmu Sosial Lainnya. Cet. pertama, Bandung: Remaja Rosdakarya.

Mulyana, Deddy dan Jalaluddin Rakhmat (ed.), 2001. Komunikasi antar Budaya. Cet. keenam, Bandung: Remaja Rosda Karya.

Nasrullah, 2002. Kuota Haji dan Hubungannya dengan Konsep Istita'ah: Studi Kasus Daftar Tunggu Calon Jamaah Haji Kabupaten Bone. Skripsi, Sekolah Tinggi Agama Islam Negeri (STAIN) Watampone.

Pusat Bahasa Departemen Pendidikan Nasional, 2001. Kamus Besar Bahasa Indonesia. Edisi Revisi.

Salam, Abdul, 2000. Implementasi dan Sosialisasi Siri': Studi Kasus pada Enam Keluarga Bugis Bone di Sulawesi Sekatan. Desertasi pada Program Pascasarjana Universitas Padjdjaran, Bandung.

Sarjan, Andi, 1999. Studi tentang Paham dan Kepercayaan Suku Bugis (Bone) di Sekitar Pelaksanaan Ibadah Haji. Hasil Penelitian Kolektif. STAIN Watampone.

Soekanto, Soerjono,1993. Kamus Sosiologi. Jakarta: RajaGrafindo Persada. 
----, 2001. Sosiologi: Suatu Pengantar. Cetakan ketiga puluh dua, Jakarta: RajaGrafindo Perkasa.

Suryoprayogo, Imam dan Tobroni, 2001. Metodologi Penelitian Sosial Agama. Cet. pertama, Bandung: Remaja Rosdakarya.

Tang, Mahmud, 1997. "Kebudayaan Bugis: Menegakkan Siri" dalam Melalatoa, M. Junus (et.al.), Sistem Budaya Indonesia. Jakarta: Pamator.

Tibi, Bassam, 1999. Islam, Kebudayaan dan Perubahan Sosial. Diterjemahkan oleh Misbah Zulfah Elizabet dan Zainul Abbas. Yogyakarta: Tiara Wacana Yogya. 